\title{
Does caffeine supplementation alter energy contribution during a work-based $\sim 30$ min cycling time-trial?
}

http://dx.doi.org/10.11606/1807-5509202000030471

\begin{abstract}
Caffeine has been shown to increase anaerobic energy contribution during short-duration cycling time-trials (T) though no information exists on whether caffeine alters energy contribution during more prolonged, aerobic type $\Pi s$. The aim of this study was to determine the effects of caffeine supplementation on longer and predominantly aerobic exercise. Fifteen recreationally-trained male cyclists (age $38 \pm 8$ y, height $1.76 \pm 0.07$ $\mathrm{m}$, body mass $72.9 \pm 7.7 \mathrm{~kg}$ ) performed a 30 min cycling $\Pi$ following either $6 \mathrm{mg} \cdot \mathrm{kg}-1 \mathrm{BM}$ caffeine (CAF) or placebo (PLA) supplementation, and one control (CON) session without supplementation, in a double-blind, randomised, counterbalance and cross-over design. Mean power output (MPO) was recorded as the outcome measure. Respiratory values were measured throughout exercise for the determination of energy system contribution. Data were analysed using mixed-models. CAF improved mean MPO compared to CON $(P=0.01)$, and a trend towards an improvement compared to PLA ( $P=0.07)$; there was no difference in MPO at any timepoint throughout the exercise between conditions. There was a main effect of Condition $(P=0.04)$ and Time $(\mathrm{P}<0.0001)$ on blood lactate concentration, which tended to be higher in CAF vs. both PLA and CON (Condition effect, both $\mathrm{P}=0.07)$. Ratings of perceived exertion increased over time $(\mathrm{P}<0.0001)$, with no effect of Condition or interaction (both $\mathrm{P}>0.05$ ). Glycolytic energy contribution was increased in CAF compared to CON and PLA (both $\mathrm{P}<0.05$ ), but not aerobic or ATP-CP (both $\mathrm{P}>0.05$ ). CAF improved aerobic $\Pi$ performance compared to $\mathrm{CON}$, which could be explained by increased glycolytic energy contribution.
\end{abstract}

KEYWORDS: Caffeine supplementation; Time-trial performance; Energy system contribution; Glycolytic.

\section{Introduction}

The rate of energy supply in a given TT will mainly depend on its intensity and duration. Shorter duration TTs (i.e., $1 \mathrm{~km} ;-1 \mathrm{~min}$ ) are considered high-intensity and predominantly limited by peripheral fatigue, and anaerobic energy distribution is considered a limiting factor for performance in such tasks ${ }^{1}$. On the other hand, middle- to longerduration TT's (i.e., $>4 \mathrm{~km}$ ) are predominantly supplied by aerobic sources, although an increased anaerobic power output contribution may be expected during specific moments, such as uphill climbs and the dispute of positions at the end of the $\mathrm{TT}^{2}$. In fact, it has been known for some time that anaerobic capacity moderately correlates to performance during middle-distance cycling TT $(\mathrm{r}=-$ $0.50)^{3}$. Thus, any nutritional intervention employed to improve anaerobic energy supply, even during cycling events that are highly aerobic in nature, could potentially improve cycling TT performance.

Caffeine is a popular ergogenic aid that has purported ergogenic properties that can impact upon both peripheral and central fatigue. Indeed, caffeine can directly affect the skeletal muscle by increasing the activity of phosphofructokinase, subsequently increasing anaerobic glycolysis ${ }^{4}$. In addition, caffeine administration has also been speculated to promote calcium release from the sarcoplasmic reticulum ryanodine receptor, 
thereby improving excitation-contraction coupling, as shown by increased force during tetanic stimulation ${ }^{5}$. Caffeine can also promote reduced levels of potassium in the muscle cell interstitium, leading to improved stimulation of the sodiumpotassium pump ${ }^{6}$. Caffeine may also act on the central nervous system as an adenosine A1 and $\mathrm{A} 2 \mathrm{~A}$ receptor antagonist, leading to an increase in motivational drive and neuromuscular excitability, which may result in a decreased perception of effort (i.e., ratings of perceived exertion; RPE) and pain for a given workload ${ }^{7}$.

The wide-ranging physiological effect of caffeine suggests it can have ergogenic properties across a variety of exercise intensities and durations. Indeed, caffeine has been shown to improve cycling TT performance of $1-^{8}, 4-{ }^{9}, 10-{ }^{10}$ and $40-{ }^{11} \mathrm{~km}$. SANTOS et al. ${ }^{9}$ showed an improved $4-\mathrm{km}$ TT performance with caffeine, although overall aerobic and anaerobic

\section{Methods}

\section{Participants}

Fifteen recreationally-trained ${ }^{13}$ male cyclists (TABLE 1) volunteered and gave their written informed consent to participate in this study. All were competitive cyclists with over one year of training experience. Participants were required not to have taken any supplements in the past 6 months, except for carbohydrate and protein, or any previous use of anabolic steroids. The study was first approved by the University of São Paulo's Ethics Review Committee.

\section{Experimental design}

Participants attended the laboratory on a total of six separate occasions, separated by a minimum of $72 \mathrm{~h}$, with all trials being performed at the same time of day to ensure results were not affected by circadian variation ${ }^{14}$. The first session was for the determination of $\mathrm{VO}_{2 \max }$ and $\mathrm{W}_{\max }$ using an incremental cycling test to exhaustion. The following two sessions were for familiarisation of the simulated TT protocol. The final three sessions comprised of the main trials in which individuals performed the TT protocol following either caffeine (CAF) or placebo (PLA) supplementation, or a control $(\mathrm{CON})$ trial. contribution was unchanged. This was despite greater anaerobic contribution in the middle section of the test with caffeine. Nonetheless, changes in mean power output (MPO) mirrored changes in anaerobic contribution, supporting the notion that power distribution throughout a TT is regulated primarily by changes in anaerobic contribution ${ }^{3}$. It is unclear whether longer duration exercise tasks with a lower contribution from anaerobic energy sources ${ }^{12}$ are improved with caffeine due to modifications in anaerobic energy contribution and subsequent power distribution.

The aim of this study was to determine the effect of caffeine supplementation on physiological and performance variables during a prolonged work-based simulated $-30 \mathrm{~min}$ cycling TT. We hypothesised that caffeine would improve exercise performance due to an increased anaerobic energy contribution.

Twenty-four hours prior to all trials, participants were required to refrain from alcohol, caffeine and any strenuous exercise. Food intake was monitored during the twenty-four hours prior to the first main trial using a food diary and replicated prior to the remaining main trials. The food diaries were analysed by a nutritionist immediately prior to the experimental sessions to ensure that participants had not consumed any caffeine containing foods while energy and macronutrient intake was analysed at a later time by the same nutritionist using specific software (Avanutri online, Avanutri, Rio de Janeiro, Brazil).

The main trials followed a double-blind, randomised, counterbalanced and cross-over design. Participants arrived at the laboratory a minimum of $6 \mathrm{~h}$ post-prandial. One hour prior to exercise in CAF and PLA, participants ingested a capsule containing either $6 \mathrm{mg} \cdot \mathrm{kg}^{-1} \mathrm{BM}$ of caffeine or dextrose alongside $500 \mathrm{~mL}$ of water before remaining seated until the commencement of exercise. In CON, participants followed the same procedure although no capsule was ingested. Participants were allowed access to their phones or own reading material throughout this waiting period. Blinding occurred via an outside researcher who prepared each participant's supplements in identical opaque capsules. Participants were 
randomly assigned to each experimental condition using a Latin Square model ${ }^{15}$.

\section{Experimental procedures}

\section{Incremental cycling capacity test}

Participants' performed an incremental cycling capacity test to exhaustion on a cycle ergometer (Lode Excalibur, Germany) to determine individual $\mathrm{VO}_{2 \max }$ and $\mathrm{W}_{\max }$. Individual set up of the cycle ergometer was determined prior to the maximal test, recorded electronically, and maintained for all subsequent trials. Participants performed four submaximal 4-min stages starting at $75 \mathrm{~W}$; this was increased by $50 \mathrm{~W}$ each stage until $225 \mathrm{~W}$. Thereafter, workload increased by $30 \mathrm{~W}$ every minute until volitional exhaustion. Ventilatory and gas exchange measurements were recorded using a portable breath-by-breath system $\left(\mathrm{K} 4 \mathrm{~b}^{2}\right.$, Cosmed, Italy); the highest value averaged over a 30-s period during the test was defined as $\mathrm{VO}_{2}$ Individual $\mathrm{W}_{\mathrm{ma}}$ was calculated as the last completed stage plus the fraction of time spent in the final non-completed stage multiplied by $30 \mathrm{~W}$.

\section{Cycling Time-Trial}

A 5-min cycling warm up was performed at $125 \mathrm{~W}$ immediately followed by the individual TT. Individuals were required to complete a predetermined amount of work equivalent to $25 \mathrm{~min}$ at $85 \%$ of their individual $\mathrm{W}_{\max }$ in the fastest possible time ${ }^{16}$; work to be completed was calculated according to the formula, "Total amount of work $=0.85 \times \mathrm{W}_{\max } \times 1500 \mathrm{~s}$ ". The cycle ergometer was set in linear mode, meaning work load was cadence dependent according to the formula, "W $=\alpha \times(\mathrm{rpm})^{2}$ ". The $\alpha$ value was based on each individual's $\mathrm{W}_{\text {max }}$ so that individuals were working at $85 \% \mathrm{~W}_{\max }$ when cycling at a cadence of $95 \mathrm{rpm}$.

Participants were instructed to complete the exercise in the fastest possible time. No motivation or specific information was given to the individuals during the test although they were informed when they had completed 25\%, 50\%, 75\% and $90 \%$ of the exercise. We have previously shown the test to have a coefficient of variation $(\mathrm{CV})$ of $2.9 \%$ following one familiarisation trial (17); the CV ((standard deviation/mean) x 100)) between familiarisation trials in the current study was $2.7 \%$.

\section{Measurements}

Minute ventilation $\left(\mathrm{V}_{\mathrm{E}}\right), \mathrm{VO}_{2}$, and respiratory exchange ratio (RER) were measured during all main experimental trials using a breath-bybreath portable gas analyser $\left(\mathrm{K} 4 \mathrm{~b}^{2}\right.$, Cosmed, Italy) that has previously been validated over a range of exercise intensities ${ }^{18}$. The gas analyser was calibrated according to the manufacturer's specifications prior to every test.

Finger-prick blood samples were taken at baseline; following completion of $25 \%, 50 \%$, $75 \%, 90 \%$ and $100 \%$ of the test; and 3, 5 and $7 \mathrm{~min}$ post-exercise. A volume of $20 \mu \mathrm{L}$ of blood was stored in the same volume of ice-cold $2 \% \mathrm{NaF}$ solution. This was then centrifuged for $5 \mathrm{~min}$ at $1 \mathrm{~g}$ at $4^{\circ} \mathrm{C}$ and the resultant plasma was then stored at $-80^{\circ} \mathrm{C}$ until analysis. Plasma lactate was determined spectrophotometrically using an enzymaticcolorimetric method (Biotecnica, MG, Brasil).

Heart rate was monitored consistently throughout exercise at a frequency of $5 \mathrm{~Hz}$ using a heart rate monitor with telemetry data transmission (Cosmed, Italy). Ratings of perceived exertion were recorded following 25\%, 50\%, 75\%, $90 \%$ and $100 \%$ of the test using the $6-20$ point Borg scale ${ }^{19}$.

\section{Calculation of the energetic system contribution}

Energy contribution was calculated according to the methods of Artioli et al. ${ }^{20}$. The net energy generated by aerobic metabolism was calculated by subtracting rest oxygen consumption from exercise oxygen consumption. Oxygen consumption was measured as the participants remained seated quietly on the ergometer for a 5-min period prior to the warm-up; the mean of the final $30 \mathrm{~s}$ of this multiplied by the exercise duration was taken as resting oxygen consumption. The area under the curve (AUC) of oxygen consumption during the entire TT was calculated using the trapezoidal method. Subsequently, resting oxygen consumption was subtracted from exercise oxygen consumption.

Estimated energy cost of the ATP-CP system was calculated using the fast component of excess post-exercise oxygen consumption by subtracting resting oxygen consumption from the oxygen consumed during the recovery period. For the calculation of the contribution of the glycolytic system, it was assumed that $1 \mathrm{mmol} \cdot \mathrm{L}^{-1}$ of lactate above resting values corresponded to 3 
$\mathrm{mL}$ of oxygen consumed per kilogram of body mass. Delta plasma lactate (i.e., end plasma lactate minus resting plasma lactate), was thus multiplied by 3 and by the athlete's body mass. The obtained value of oxygen in millilitres was converted to litres and subsequently to energy $(\mathrm{kJ})$, assuming that each $1 \mathrm{~L}$ of oxygen is equal to $20.92 \mathrm{~kJ}^{20}$.

The result obtained from each energy system was summed and the total energy expenditure calculated. Total metabolic work (TMW) was calculated as the sum of the energy systems according to previous methods ${ }^{21-24}$ and based upon assumptions described by di Prampero and FerRetTi ${ }^{25}$.

\section{Statistical Analysis}

All data were analysed using the SAS statistical package, (SAS 9.2, SAS Institute Inc., USA) and are presented as mean $\pm 1 S D$. Statistical significance was accepted at $\mathrm{P} \leq 0.05$. Mixed-model analyses with repeated measures were used to compare the overall effect of caffeine on TT performance

\section{Results}

There was no effect of trial order on $\mathrm{MPO}(\mathrm{P}=$ 0.58). There was a main effect of Condition on overall MPO $(\mathrm{P}=0.001)$, with an improved performance in CAF vs. CON $(+3.8 \pm 5.4 \%, 243.7 \pm 32.8$ vs. 235.7 $\pm 37.0 \mathrm{~W}, \mathrm{P}=0.01,92 \%$ likely positive), and a trend towards significance between CAF and PLA $(+2.7 \pm$ $3.8 \%, 243.7 \pm 32.8$ vs. $237.8 \pm 34.5 \mathrm{~W}, \mathrm{P}=0.07$, $87 \%$ likely positive). There was no statistical difference between PLA and CON $(+1.1 \pm 3.4 \%, 237.8 \pm 34.5$ vs. $235.7 \pm 37.0 \mathrm{~W}, \mathrm{P}=0.71,70 \%$ possibly trivial). Nine individuals improved above the variation of the test in $\mathrm{CAF}$ vs. CON and eight vs. PLA; three individuals improved about the CV in PLA vs. CON.

There was a main effect of Time $(\mathrm{P}<0.0001)$ on MPO throughout the TT, but no main effect of Condition or a Condition $\mathrm{x}$ Time interaction ( $\mathrm{P}$ $=0.93) ; \mathrm{MPO}$ was not different between trials at any time point throughout exercise (FIGURE 1). Magnitude based inferences showed that MPO was possibly to likely improved in CAF throughout the TT, except during the final $10 \%$ of the test (TABLE 2).

There was a main effect of Condition $(\mathrm{P}=$ $0.04)$ and Time $(\mathrm{P}<0.0001)$ on blood lactate and energy contribution (aerobic, glycolytic, ATP-CP) with Condition (CON, PLA and CAF) used as a fixed factor and participants as a random factor. A mixed-model was used to analyse the effect of caffeine on RPE, where Condition (CON, PLA and CAF) and Time $(0,25,50,75,90$ and $100 \%)$ were considered fixed factors. Another mixed-model was used to determine the effect on lactate, with Trial (CON, PLA and CAF) and Time (0, 25, 50, 75, 90 and $100 \%, 3,5$ and 7 min post-exercise) considered fixed factors. Magnitude based inference ${ }^{26}$ were used to determine the practical significance of caffeine on TT performance (overall and throughout the exercise) using a spreadsheet to establish the likelihood of a meaningful effect on exercise capacity. The smallest worthwhile improvement in MPO was calculated using half the CV of the test ${ }^{27,28}$ from Oliveira et al. ${ }^{17}$. Qualitative descriptors were assigned to the positive percentile scores as follows: $<1 \%$, almost certainly not; $1-5 \%$, very unlikely; 5-25\%, unlikely; 25-75\%, possibly; 75-95\%, likely; 95$99 \%$, very likely; >99\%, almost certainly.

concentration, although only a tendency towards a Condition $\mathrm{x}$ Time interaction $(\mathrm{P}=0.07)$. Blood lactate tended to be higher in CAF vs. both PLA and CON (Condition effect, both $\mathrm{P}=0.07$ ), with no differences between trials at specific time points (FIGURE 2, PANEL A). RPE increased over time $(P<0.0001)$, although there was no effect of Condition $(\mathrm{P}=0.80)$ or a Condition $\mathrm{x}$ Time interaction $(\mathrm{P}=0.97)$ (FIGURE 2, PANEL B).

\section{Energy system contribution}

There was no main effect of Condition on absolute aerobic energy contribution $(\mathrm{P}=0.84)$ or on absolute ATP-CP contribution $(\mathrm{P}=0.34)$. There was a main effect of Condition on absolute glycolytic energy contribution $(\mathrm{P}=0.02)$, with higher contribution shown in CAF vs. CON (TABLE 3). There was a significant main effect of Condition on the relative aerobic contribution $(\mathrm{P}=0.01)$, with lower relative contribution in CAF than CON $(\mathrm{P}<0.05)$. Similarly, there was a significant main effect of condition on the relative glycolytic contribution 
$(P=0.01)$; relative glycolytic contribution was higher in CAF compared to both PLA and CON (both $\mathrm{P}<0.05$; TABLE 3). There were no differences in ATP-CP relative contribution $(\mathrm{P}>0.05)$. There was no effect of Condition on TMW $(\mathrm{P}=0.92)$.

TABLE 1 - Participant characteristics.

\begin{tabular}{|c|c|c|c|c|}
\hline \multirow{2}{*}{\multicolumn{2}{|c|}{ Characteristic }} & \multirow{2}{*}{ Mean (SD) } & \multicolumn{2}{|c|}{ Range } \\
\hline & & & Min & $\operatorname{Max}$ \\
\hline \multicolumn{2}{|l|}{ Age $(y)$} & $38(8)$ & 29 & 55 \\
\hline \multicolumn{2}{|l|}{ Height (cm) } & $1.76(0.07)$ & 1.60 & 1.85 \\
\hline \multicolumn{2}{|l|}{ Body mass (kg) } & $72.9(7.7)$ & 58.9 & 93.0 \\
\hline \multicolumn{2}{|l|}{ Experience (months) } & $12(11)$ & 2 & 40 \\
\hline \multirow{2}{*}{ Weekly training } & Duration (h) & $10(4)$ & 6 & 18 \\
\hline & Distance $(\mathrm{km})$ & $272(120)$ & 140 & 500 \\
\hline \multirow{2}{*}{$\mathrm{VO}_{2 \max }$} & Absolute $\left(\mathrm{L} \cdot \mathrm{min}^{-1}\right)$ & $3.7(0.4)$ & 2.8 & 4.6 \\
\hline & Relative $\left(\mathrm{ml} \cdot \mathrm{kg} \cdot \mathrm{min}^{-1}\right)$ & $51.1(7.1)$ & 40.7 & 63.9 \\
\hline \multicolumn{2}{|l|}{$\mathrm{HR}_{\max }$ (beats. $\min ^{-1}$ ) } & $186(11)$ & 169 & 201 \\
\hline $\mathrm{W}_{\max }$ & Absolute (W) & $346(42)$ & 285 & 410 \\
\hline \multirow{2}{*}{ Habitual caffeine intake } & Absolute (mg.day $\left.{ }^{-1}\right)$ & $182(121)$ & 50 & 456 \\
\hline & Relative $\left(\mathrm{mg} \cdot \mathrm{kg}^{-1} \mathrm{BM} \cdot\right.$ day $\left.^{-1}\right)$ & $2.5(1.7)$ & 0.8 & 6.3 \\
\hline
\end{tabular}

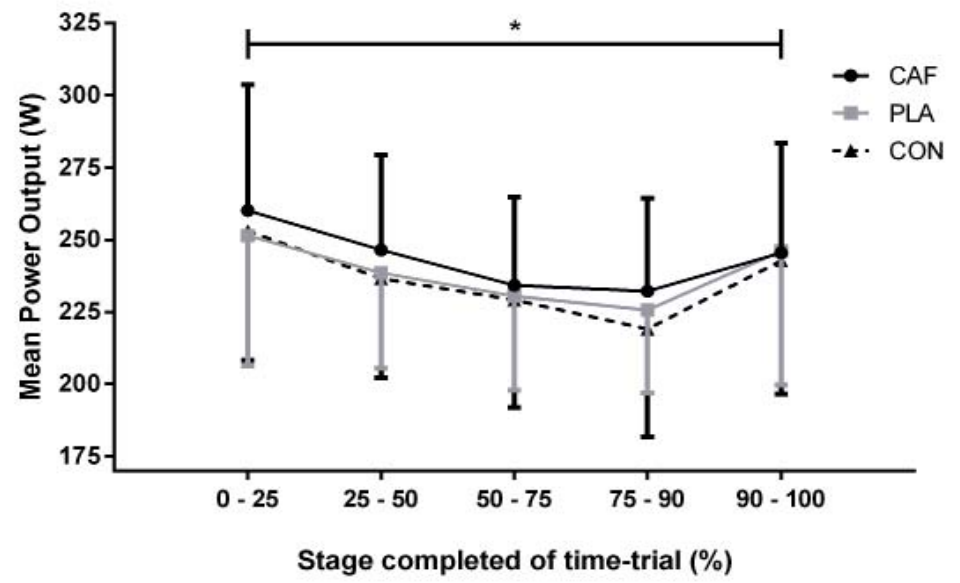

FIGURE 1 - Mean power output following completion of 25, 50, 75, 90 and 100\% of the time-based time-trial in caffeine (CAF), placebo (PLA) and control (CON). 
Barreto G, et al.

TABLE 2 - Magnitude based inferences of the difference in mean power output throughout the exercise.

${ }^{*} \mathrm{P}<0.05$ Main effect of Time. ${ }^{\wedge} \mathrm{P}<0.05$ Main effect of Condition.

\begin{tabular}{lccc}
\hline & CAF vs. CON & CAF vs. PLA & PLA vs. CON \\
\hline $\mathbf{0 - 2 5 \%}$ & $68 / 31 / 1$ & $81 / 18 / 0$ & $7 / 71 / 22$ \\
$\mathbf{2 5 - 5 0 \%}$ & $97 / 3 / 0$ & $93 / 7 / 0$ & $28 / 70 / 1$ \\
$\mathbf{5 0 - 7 5 \%}$ & $53 / 44 / 2$ & $39 / 60 / 1$ & $18 / 76 / 6$ \\
$\mathbf{7 5 - 9 0 \%}$ & $92 / 8 / 0$ & $53 / 46 / 1$ & $52 / 47 / 0$ \\
$\mathbf{9 0 - 1 0 0 \%}$ & $15 / 81 / 4$ & $5 / 87 / 8$ & $14 / 85 / 2$ \\
$\mathbf{0 - 1 0 0 \%}$ & $92 / 8 / 0$ & $87 / 13 / 0$ & $29 / 70 / 1$ \\
\hline
\end{tabular}

${ }^{*} \mathrm{P}<0.05$ Main effect of Time.

$\wedge \mathrm{P}<0.05$ Main effect of Condition.

${ }^{*} \mathrm{P}<0.05$ Main effect of Time.

A

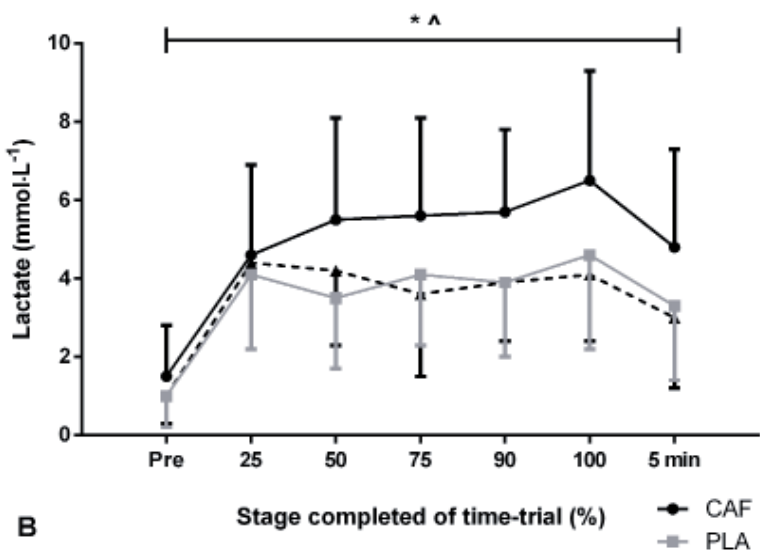

B

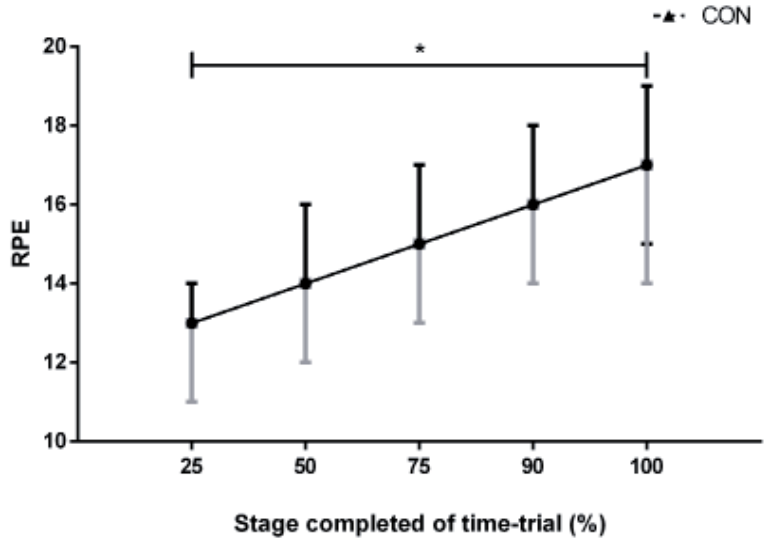

FIGURE 2 - Panel A. Blood lactate concentration at pre-exercise(Pre), following completion of 25, 50, 75, 90 and $100 \%$ of the time-based time-trial, and 5 -minutes post-exercise ( $5 \mathrm{~min}$ ) in caffeine (CAF), placebo (PLA) and control (CON). Panel B. Ratings of perceived exertion (RPE) following completion of 25, $50,75,90$ and $100 \%$ of the time-based time-trial in caffeine (CAF), placebo (PLA) and control (CON).

476 • Rev Bras Educ Fís Esporte, (São Paulo) 2020 J ul-Set;34(3):471-81 
TABLE 3 - Absolute and relative energy contribution from oxidative, ATP-CP and Glycolytic energy sources, and total metabolic work (TMW) during the cycling time-trial during the caffeine (CAF), placebo (PLA) and control (CON) sessions.

\begin{tabular}{|c|c|c|c|c|c|c|c|c|c|c|c|c|}
\hline & \multicolumn{4}{|c|}{ CAF } & \multicolumn{4}{|c|}{ PLA } & \multicolumn{4}{|c|}{ PLA } \\
\hline & Mean & SD & Min & Max & Mean & SD & Min & $\operatorname{Max}$ & Mean & SD & Min & $\operatorname{Max}$ \\
\hline \multicolumn{13}{|l|}{ Oxidative } \\
\hline Absolute (kJ) & 1.882 & 0.190 & 1.489 & 2.164 & 1.855 & 0.208 & 1.497 & 2.168 & 1.889 & 0.220 & 1.602 & 2.324 \\
\hline Relative (\%) & $96.8^{*}$ & 0.7 & 95.6 & 97.7 & 97.2 & 0.5 & 96.4 & 98.2 & 97.5 & 0.5 & 96.2 & 98.2 \\
\hline \multicolumn{13}{|l|}{ ATP-CP } \\
\hline Absolute (kJ) & 29.2 & 9.9 & 11.0 & 49.0 & 28.1 & 14.4 & 8.0 & 58.0 & 24.0 & 7.5 & 13.0 & 34.0 \\
\hline Relative (\%) & 1.4 & 0.5 & 0.6 & 2.6 & 1.5 & 0.6 & 0.5 & 2.6 & 1.2 & 0.3 & 0.6 & 1.8 \\
\hline \multicolumn{13}{|l|}{ Glycolytic } \\
\hline Absolute (kJ) & $31.6^{*}$ & 13.1 & 11.0 & 57.0 & 23.8 & 7.7 & 11.0 & 40.0 & 21.9 & 8.2 & 8.0 & 39.0 \\
\hline Relative (\%) & $1.6^{*} \#$ & 0.6 & 0.5 & 2.5 & 1.1 & 0.3 & 0.5 & 1.6 & 1.1 & 0.4 & 0.3 & 1.9 \\
\hline TMW (kJ) & 1.941 & 0.202 & 1.552 & 2.260 & 1.936 & 0.225 & 1.536 & 2.241 & 1.934 & 0.211 & 1.640 & 2.365 \\
\hline
\end{tabular}

${ }^{*} \mathrm{P}<0.05$ from

$\mathrm{CON}$;

$\# \mathrm{P}<0.05$ from

PLA.

\section{Discussion}

The main findings of this study showed that caffeine increased overall MPO during a simulated -30 min TT. The improvement with caffeine could be partly explained by a parallel increase in glycolytic energy contribution.

Caffeine supplementation improved cycling performance compared to the control condition in which no supplement was ingested, but failed to reach significance compared to the placebo trial. This was, perhaps, somewhat unexpected, although this could be partially explained by expectancy. When an individual receives a supplement, whether it contains the active ingredient or an inert substance, this can increase their expectancy of obtaining a positive improvement. A positive outcome stemming from the belief that a positive intervention has been received is called the placebo effect ${ }^{29}$. We have previously shown that expectancy associated with caffeine supplementation may modify the ergogenic effect of both the active intervention and the placebo session ${ }^{30}$. Other studies have also demonstrated the ergogenic potential of expectancy with caffeine supplementation ${ }^{31}$. Thus, the current data suggest that part of the ergogenic effect shown here with caffeine supplementation may be due to the placebo effect, although the placebo trial was not improved compared to the control. Although the current results showed that caffeine could improve -30 min cycling TT performance via an increased overall MPO, there was no modification in pacing strategy throughout the exercise. This is in contrast to previous research showing an altered pacing strategy with caffeine during a $4 \mathrm{~km} \mathrm{TT}^{9}$; individuals maintained a higher MPO in the middle of the test with caffeine. In the current study, no statistical differences were shown at any time point between trials, though it could be argued that routine analyses may not have been sensitive enough to detect small but potentially worthwhile differences. Closer inspection of pacing suggests that caffeine supplementation resulted in moderate increases in MPO throughout the test, except for the final 10\%. Indeed, magnitude based inferences suggest that the differences during these sections were possibly to likely meaningful, and it is possible that the cumulation of these increased power outputs over the different time points led to the overall improvement with caffeine compared to the control session. Thus, it appears that caffeine resulted in small, but potentially worthwhile, increases in MPO throughout the TT.

As expected, the majority of energy provision came from aerobic sources during the $-30 \mathrm{~min}$ TT. Despite this, we showed that overall glycolytic energy contribution was higher with caffeine compared to the control trial; the relative contribution from glycolytic energy sources (to total energy expenditure) was higher with caffeine compared to both the control and placebo trial. These results contrast with those of SANTOS et al. ${ }^{9}$, who showed no overall changes in anaerobic contribution with caffeine during a $4-\mathrm{km}$ 
TT, although they did not separate glycolytic from ATP-CP contribution. Despite this, their results did show greater anaerobic contribution at several isolated time points throughout the TT. Unfortunately, in the current study we were unable to calculate energy contribution at different time points throughout the TT, which could have provided more information regarding the exact moments at which individuals were able to maintain an increased glycolytic energy contribution. Nonetheless, our results suggest that the improved performance shown here with caffeine may be partly due to an increased glycolytic energy contribution meaning they could maintain a higher mean power output throughout exercise. This was mirrored by a trend towards increased blood lactate values with caffeine, also indicative of an increased glycolytic energy contribution. However, the absolute increases in glycolytic energy contribution were low, and it is known that the effect of caffeine is pleiotropic. Therefore, it cannot be ruled out that the mechanism by which performance was improved was also due to caffeine's other mechanisms of action.

Our results reaffirm the sports-performance enhancing properties of caffeine, and yet, only 9 and 8 out of 15 individuals improved their performance (above the test CV) compared to control and placebo. The reasons for this inter-individual variation is not entirely clear but could be due to genetic variation in caffeine metabolism or differences in habitual caffeine consumption. Single nucleotide polymorphism of the CYP1A2 gene responsible for caffeine metabolism leads to fast (TT allele homozygotes and slow (C allele carriers) metabolizer ${ }^{32}$, although the influence of these polymorphisms on the response to acute caffeine supplementation is inconsistent ${ }^{33-35}$ and beyond the scope of this study. Habitual consumption of caffeine has been suggested to modify the acute response to caffeine supplementation ${ }^{36}$, although more recent data from our lab suggests otherwise ${ }^{37}$. Differences may have been due to the relative doses given as BEAUMONT et $a l .^{36}$ gave an acute dose equal to that of habitual consumption $\left(0.3 \mathrm{~g} \cdot \mathrm{kg}^{-1} \mathrm{BM}\right)$ whereas GonÇALVES et al. ${ }^{37}$ gave an acute dose in excess of average intake. Here our acute dose was well in excess of the habitual intake of our volunteers ( $6 \mathrm{vs} .2 .5 \mathrm{mg} \cdot \mathrm{kg}^{-1} \mathrm{BM}$ ) and thus cannot explain the lack of an effect in some individuals.

There are two main limitations with the current investigation. Firstly, we were unable to measure caffeine concentration, although we are certain that the relatively high dose used here resulted in sufficient increases to elicit an ergogenic effect ${ }^{38}$. A further limitation of this study is that we were unable to calculate energy systems contribution at various time points throughout the cycling TT. This is due to the method employed ${ }^{20}$ and the variable lactate concentrations throughout the test. The method requires subsequent lactate values to be higher than the previous measure, to accurately determine energy contribution during that period. However, since pacing during cycling exhibits a " $U$ "-pacing profile ${ }^{39}$ with an unsustainable high power output at the beginning, this meant that lactate concentration following the initial section of the TT was higher than the subsequent sections, hampering our calculations. Further research should use methods that allow quantification of the contribution of all energy systems at time points throughout more prolonged cycling TT performance.

In summary, our results showed that caffeine can improve MPO during a $-30 \mathrm{~min}$ TT, and an increased glycolytic energy contribution may have contributed to this improved performance. Despite an overall improved performance, pacing was not changed with caffeine. Our results highlight the importance of anaerobic metabolism even during predominantly aerobic based activity and demonstrate that the ergogenic effect of caffeine is via an increased contribution from glycolytic energy sources. These data suggest that cyclists can expect to experience moderate but potentially worthwhile gains in performance with caffeine during aerobic cycling TTs.

\section{Acknowledgements}

Rafael Pires da Silva (2012/13026-5), Vitor de Salles Painelli (2013/04806-0), Bruno Gualano (2013/14746-4) and Bryan Saunders (2016/50438-0 and 2017/04973-4) have been financially supported by Fundação de Amparo à Pesquisa do Estado de Sao Paulo (FAPESP). Luana Farias de Oliveira has been financially supported by Coordenação de Aperfeiçoamento de Pessoal de Nível Superior (CAPES).

We wish to thank the Laboratório de Determinantes Energéticos de Desempenho Esportivo (LADESP) for access to the cycle ergometer used in this study. 


\section{Conflict of interest}

The authors declare that they do not have conflict of interests.

\section{Resumo}

A suplementação de cafeína altera a contribuição energética durante um contra-relógio de 30 minutos baseado em trabalho realizado?

Tem sido demonstrado que a cafeína tem a capacidade de aumentar a contribuição energética durante contra-relógios de curta duração de ciclismo, mas não se sabe se a cafeína altera a contribuição energética durante contra-relógios aeróbios, mais prolongados. 0 objetivo deste estudo foi determinar os efeitos da cafeína em exercícios mais longos e predominantemente aeróbios. Quinze atletas do sexo masculino treinados recreacionalmente (idade $38 \pm$ anos, altura $1.76 \pm 0.07 \mathrm{~m}$, massa corpórea $72.9 \pm 7.7 \mathrm{~kg}$ ) realizaram um contra-relógio de ciclismo de $\sim 30 \mathrm{~min}$ após a suplementação com $6 \mathrm{mg} \cdot \mathrm{kg}-1 \mathrm{MC}$ de cafeína (CAF) ou placebo (PLA) e uma sessão controle (CON) sem suplementação, de modo duplo-cego, randomizado, contrabalanceado e cross-over. A potência média (MPO) foi registrada como a parâmetro de avaliação. Valores respiratórios foram medidos através do exercício para a determinação da contribuição energética. Os dados foram analisados usando modelos mistos. CAF aumentou o MPO comparado ao CON $(P=0,01)$, e uma tendência para uma melhoria comparado ao PLA $(P=0,07)$; não houve diferenças no MPO em nenhum ponto através do exercício entre as condições. Houve um efeito principal de Condição $(P=0,04)$ e Tempo $(P<0,0001)$ na concentração de lactato, que tendeu a ser maior em CAF vs. PLA e CON (efeito de Condição, ambos $P=0,07)$. As classificações do esforço percebido aumentaram ao longo do tempo $(P<0,0001)$, sem efeito de Condição ou interação (ambos $P>0,05$ ). A contribuição energética do sistema glicolítico aumentou com CAF comparada ao COM e PLA (ambos $\mathrm{P} \leq 0,05$ ), e a contribuição anaeróbia e do sistema ATP-CP, não (ambos $P>0,05$ ). 0 grupo CAF melhorou sua performance em contra-relógio aeróbio comparada ao CON, provavelmente devido ao aumento da contribuição energética glicolítica.

Palavras-chave: Suplementação de cafeína; Desempenho contra-relógio; contribuição energética; Glicolítico.

\section{References}

1. de Jong J, van der Meijden L, Hamby S, Suckow S, Dodge C, de Koning JJ, et al. Pacing strategy in short cycling time trials. Int J Sports Physiol Perform. 2015;10(8):1015-22.

2. Corbett J, Barwood MJ, Ouzounoglou A, Thelwell R, Dicks M. Influence of competition on performance and pacing during cycling exercise. Med Sci Sports Exerc. 2012;44(3):509-15.

3. Craig NP, Norton KI, Bourdon PC, Woolford SM, StanefT, Squires B, et al. Aerobic and anaerobic indices contributing to track endurance cycling performance. Eur J Appl Phys Occup Physiol. 1993;67(2):150-8.

4. Simmonds MJ, Minahan CL, Sabapathy S. Caffeine improves supramaximal cycling but not the rate of anaerobic energy release. Eur J Appl Physiol. 2010;109(2):287-95.

5. Tarnopolsky M, Cupido C. Caffeine potentiates low frequency skeletal muscle force in habitual and nonhabitual caffeine consumers. J Appl Physiol (1985). 2000;89(5):1719-24.

6. Mohr M, Nielsen JJ, Bangsbo J. Caffeine intake improves intense intermittent exercise performance and reduces muscle interstitial potassium accumulation. J Appl Physiol (1985). 2011;111(5):1372-9.

7. Doherty M, Smith PM. Effects of caffeine ingestion on rating of perceived exertion during and after exercise: a meta-analysis. Scand J Med Sci Spor. 2005;15(2):69-78.

8. Wiles JD, Coleman D, Tegerdine M, Swaine IL. The effects of caffeine ingestion on performance time, speed and power during a laboratory-based $1 \mathrm{~km}$ cycling time-trial. J Sports Sci. 2006;24(11):1165-71. 
9. Santos RA, Kiss MA, Silva-Cavalcante MD, Correia-Oliveira CR, Bertuzzi R, Bishop DJ, et al. Caffeine alters anaerobic distribution and pacing during a 4000-m cycling time trial. PloS one. 2013;8(9):e75399.

10. Astorino TA, Cottrell T, Lozano AT, Aburto-Pratt K, Duhon J. Increases in cycling performance in response to caffeine ingestion are repeatable. Nutr Res. 2012;32(2):78-84.

11. Foad AJ, Beedie CJ, Coleman DA. Pharmacological and psychological effects of caffeine ingestion in 40-km cycling performance. Med Sci Sports Exerc. 2008;40(1):158-65.

12. Walker GJ, Dziubak A, Houghton L, Prendergast C, Lim L, Bishop NC. The effect of caffeine ingestion on human neutrophil oxidative burst responses following time-trial cycling. J Sports Sci. 2008;26(6):611-9.

13. De Pauw K, Roelands B, Cheung SS, de Geus B, Rietjens G, Meeusen R. Guidelines to classify subject groups in sport-science research. Int J Sports Physiol Perform. 2013;8(2):111-22.

14. Fernandes AL, Lopes-Silva JP, Bertuzzi R, Casarini DE, Arita DY, Bishop DJ, et al. Effect of time of day on performance, hormonal and metabolic response during a 1000-M cycling time trial. PloS one. 2014;9(10):e109954.

15. Mason RLGRFHJL. Statistical design and analysis of experiments: with applications to engineering and science. 2nd ed Hoboken, NJ; John Wiley \& Sons, Inc. 2003:328-31.

16. Jeukendrup AE, Hopkins S, Aragon-Vargas LF, Hulston C. No effect of carbohydrate feeding on $16 \mathrm{~km}$ cycling time trial performance. Eur J Appl Physiol. 2008;104(5):831-7.

17. Oliveira LF, Yamaguchi G, Painelli VS, Silva RP, Gonçalves LS, Gualano B, et al. Comprehensive reliability analysis of a $16 \mathrm{~km}$ simulated cycling time-trial in well-trained individuals. J Sci Cycling. 2017;6(1):11-7.

18. McLaughlin JE, King GA, Howley ET, Bassett DR, Jr., Ainsworth BE. Validation of the COSMED K4 b2 portable metabolic system. Int J Sports Med. 2001;22(4):280-4.

19. Borg GA. Perceived exertion. Exerc Sport Sci Rev. 1974;2:131-53.

20. Artioli GG, Bertuzzi RC, Roschel H, Mendes SH, Lancha AH, Jr., Franchini E. Determining the contribution of the energy systems during exercise. J Vis Exp. 2012(61).

21. Beneke R, Beyer T, Jachner C, Erasmus J, Hutler M. Energetics of karate kumite. Eur J Appl Physiol. 2004;92(45):518-23.

22. Franchini E, Sterkowicz S, Szmatlan-Gabrys U, Gabrys T, Garnys M. Energy system contributions to the special Judo fitness test. Intj Sport Physiol. 2011;6(3):334-43.

23. Lopes-Silva JP, Santos JFS, Branco BHM, Abad CCC, Oliveira LF, Loturco I. Caffeine ingestion increases estimated glycolytic metabolism during Taekwondo combat simulation but does not improve performance or parasympathetic Reactivation. PloS Oone. 2016;11(10).

24. Mello FD, Bertuzzi RCD, Grangeiro PM, Franchini E. Energy systems contributions in 2,000 m race simulation: a comparison among rowing ergometers and water. Eur J Appl Physiol. 2009;107(5):615-9.

25. di Prampero PE, Ferretti G. The energetics of anaerobic muscle metabolism: a reappraisal of older and recent concepts. Resp Physiol. 1999;118(2-3):103-15.

26. Batterham AM, Hopkins WG. Making meaningful inferences about magnitudes. Intj Sport Physiol. 2006;1(1):50-7.

27. Hopkins WG. Probabilities of clinical or practical significance. Sport Sci. 2002;6:431.

28. Paton CD, Hopkins WG. Ergometer error and biological variation in power output in a performance test with three cycle ergometers. Inter J Sports Med. 2006;27(6):444-7.

29. Beedie CJ, Foad AJ. The placebo effect in sports performance: a brief review. Sports Med. 2009;39(4):313-29.

30. Saunders B, de Oliveira LF, da Silva RP, de Salles Painelli V, Goncalves LS, Yamaguchi G, et al. Placebo in sports nutrition: a proof-of-principle study involving caffeine supplementation. Scand J Med Sci Sports. 2017;27(11):1240-7.

31. Beedie CJ, Stuart EM, Coleman DA, Foad AJ. Placebo effects of caffeine on cycling performance. Med Sci Sports Exerc. 2006;38(12):2159-64.

32. Sachse C, Brockmoller J, Bauer S, Roots I. Functional significance of a C: a polymorphism in intron 1 of the cytochrome P450 CYP1A2 gene tested with caffeine. Br J Clin Pharmacol. 1999;47(4):445-9.

33. Pataky MW, Womack CJ, Saunders MJ, Goffe JL, D'Lugos AC, El-Sohemy A, et al. Caffeine and 3-km cycling performance: Effects of mouth rinsing, genotype, and time of day. Scand J Med Sci Sports. 2016;26(6):613-9.

34. Womack CJ, Saunders MJ, Bechtel MK, Bolton DJ, Martin M, Luden ND, et al. The influence of a CYP1A2 polymorphism on the ergogenic effects of caffeine. J Inter Soc Sports Nutr. 2012;9(1):7.

35. Salinero JJ, Lara B, Ruiz-Vicente D, Areces F, Puente-Torres C, Gallo-Salazar C, et al. CYP1A2 genotype variations do not modify the benefits and drawbacks of caffeine during exercise: A Pilot Study. Nutrients. 2017;9(3).

36. Beaumont R, Cordery P, Funnell M, Mears S, James L, Watson P. Chronic ingestion of a low dose of caffeine induces 
tolerance to the performance benefits of caffeine. J Sports Sci. 2017;35(19):1920-7.

37. Goncalves LS, Painelli VS, Yamaguchi G, Oliveira LF, Saunders B, da Silva RP, et al. Dispelling the myth that habitual caffeine consumption influences the performance response to acute caffeine supplementation. J Appl Physiol (1985). 2017;123(1):213-20.

38. Graham TE. Caffeine and exercise: metabolism, endurance and performance. Sports Med. 2001;31(11):785-807.

39. Abbiss CR, Laursen PB. Describing and understanding pacing strategies during athletic competition. Sports Med. 2008;38(3):239-52.

\begin{tabular}{r|r} 
ADDRESS \\
Bryan Saunders \\
University of São Paulo \\
Faculty of Medecine & \\
Rheumatology Division & Submitted: 12/28/2017 \\
Revised: 02/08/2018 \\
Applied Physiology and Nutrition Research Group & Accepted: 03/07/2018 \\
Av. Dr. Arnaldo, 455 - Cerqueira César & \\
01246-903 - São Paulo - SP - Brazil & \\
E-mail: drbryansaunders@outlook.com & \\
& \\
\hline
\end{tabular}

